\title{
Comments on the occurrence and biology of Xylomoia graminea (Graeser, 1889) (Lepidoptera: Noctuidae) from south-eastern Poland
}

\author{
Jarosław BURY ${ }^{1}$ and Paweł CZUDEC ${ }^{2}$ \\ ${ }^{I}$ Markowa 1498,37-120 Markowa, Poland; e-mail: jarekbury2@wp.pl (corresponding author) \\ ${ }^{2}$ Malczewskiego 3/44, 35-114 Rzeszów, Poland; e-mail: cumel@op.pl
}

\begin{abstract}
The aim of the study was to recognize the current distribution and biology of the noctuid moth - Xylomoia graminea (Graeser, 1889) which was spreading in the Podkarpacie (SE Poland) in recent years. The material includes observations collected from 2012 to 2018 from two macroregions: Kotlina Sandomierska and Pogórze Środkowobeskidzkie. The paper contains a number of details on phenology and biology of the species - the female's behaviour during oviposition, host plant, eggs and young caterpillars up to the 3rd stage, which are illustrated with photos.
\end{abstract}

Key words: Noctuinae, Xylomoia graminea distribution, faunistic data, life cycle, SE Poland

\section{INTRODUCTION}

Xylomoia graminea (Graeser, 1889) is a member of the family Noctuidae Latreille, 1809, subfamily Noctuinae Latreille, 1809 and the worldwide genus Xylomoia Staudinger, 1892, which is represented by six species in the Palaearctic Region and by four in Europe $-X$. fuse Sugi, 1976 found in Japan; X. apameoides Hacker, 1989 found in Turkey; X. retinax Mikkola, 1998; X. graminea (Graeser, 1889) known from Europe and Asia; X. stangelmaieri Mikkola, 1998 and $X$. strix Mikkola, 1980 occurring only in Europe. In general, all these species are poorly known both in terms of distribution and biology. Relatively well-known is $X$. strix from North and East Europe including Poland and $X$. graminea characterized by the Euro-Siberian distribution type, which current range includes a large part of the temperature zone of Europe and Asia, extending from Japan, Korea, northern China and the Russian Far East to eastern and southern regions of Poland (Mikkola 1998, Karsholt \& Nieukerken 2011, Bury \& Zajda 2012).

In Europe $X$. graminea occurs in Poland, where is found in many localities, in Ukraine, Russia and Lithuania (Nowacki 1989, Klyuchko 1995, Poltavsky \& Artohin 2000, Klyuchko et al. 2001, Zilli 2005, Karsholt \& Nieukerken 2011, Švitra et al. 2011).

The study on the distribution range of $X$. graminea in Poland started in 1988, when the species was revealed for the first time in the Roztocze Południowe and Roztocze Środkowe mesoregions (Nowacki 1989). In subsequent years several new sites were discovered in northeastern and eastern Poland within the following mesoregions: Równina Augustowska (Kokot 1995), Równina Łęczyńsko-Włodawska, Wysoczyzna Siedlecka, Podlaski Przełom Bugu and in Równina Bielska (Nowacki 1993, Łupiński 1996, Nowacki \& Hołowiński 1999, Wąsala 2001, Łupiński \& Wasiluk 2002). Additional few sites were discovered till 2008 in the mesoregions Równina Augustowska and Kotlina Biebrzańska (Nowack \& Wasiluk 2004, EBS 2008, Nowacki \& Frackiel 2010). In 2008 the species was found for the first time in the mesoregion of Góry Świętokrzyskie west to the Wisła River Valley (Nowacki \& Nowacka 2012) and in 2010 it was revealed for the first time in Podkarpacie and Małopolska within the following mesoregions: Pogórze Dynowskie, Kotlina Jasielsko-Krośnieńska, Pogórze Wiśnickie and Garb Tenczyński, at a considerable distance from the previously known sites in 
the east of Poland (Olbrycht \& Bury 2011, Bury \& Zajda 2012). In the next years up to 2015 the species was also taken in a few new locations in the Podkarpacie Region as well as in The Maria Curie-Skłodowska University Botanical Garden in Lublin on the mesoregion of Płaskowyż Nałęczowski (Nowacki \& Pałka 2013, 2015, Dawidowicz \& Kucharczyk 2016).

Just like its related species $X$. graminea is associated with primeval moist habitats, predominantly lush sedge meadows, transitory bogs and rush communities (Buszko 2004, 2010, Bury \& Zajda 2012, Nowacki \& Pałka 2016). The species flies in one generation per year in the periods depending on the place of occurrence - in the western part of the range mature individuals occur from the end of May until early July, while in the east they can be observed even in mid-August (Nowacki \& Hołowiński 1999, Mikkola 1980, 1998, Sviridov 1985).

In contrast to a relatively large number of $X$. graminea distribution data from Poland there are no observations about its biology from this country. The biology of the species is poorly know. The caterpillar was shortly described by Ahola and Silvonen (2008). No descriptions of host plants of the caterpillars and the overwintering stage in nature are available. In laboratory conditions caterpillars have been reared on Phragmites sp. in an ex ovo rearing process (Ahola \& Silvonen 2008).

The aim of the study was to recognize and update the knowledge about the current distribution of $X$. graminea as well as to acquire data on its biology in conditions of southeastern Poland.

\section{MATERIAL AND METHODS}

Data from the Podkarpacie region (SE Poland) were collected in the period 2012-2018 by observers: Jarosław Bury, Paweł Czudec, Wojciech Guzik, Krzysztof Mazur and Filip Paluch. All observed moths were attracted to incandescent, fluorescent or UV lamps. The specimens were captured and preserved in a typical way for Macrolepidoptera. Voucher specimens were deposited in the authors' private collections. Some mature individuals were documented without collecting them. Alive fertilized females acquired to light traps were used in an ex ovo rearing in natural and laboratory conditions - temperature and day-night regime like in nature. Three 1st instar stages of the breeding process were documented by photographs.

Mesoregion and macroregion names are given according to Kondracki (2002). UTM (Universal Transverse Mercator) co-ordinates (10x10 km grid) are given for each locality.

\section{RESULTS}

\section{Observations of the adult form in Podkarpacie in the period 2012-2018}

1. Pogórze Środkowobeskidzkie - Kotlina Jasielsko-Krośnieńska: Umieszcz [EA30], 30 May 2013, 1 ex., 7 Jun 2013, 1 ex., 17 Jun 2013, 1 ex., 1 Jun 2014, 1 ex., 3 Jun 2014, 1 ex., 7 Jun 2014, 1 ex., 31 May 2017, 1 ex., 3 Jun 2018, 1 ex., 7 Jun 2018, 1 ex. leg. $\mathrm{K}$. Mazur, a clearing in a moist mixed forest.

2. Pogórze Środkowobeskidzkie - Kotlina Jasielsko-Krośnieńska: Tarnowiec [EA40], 6 Jun 2018, 1 ex. leg K. Mazur.

3. Pogórze Środkowobeskidzkie - Kotlina Jasielsko-Krośnieńska: Krosno [EA50], 20 Jun 2012, 1 ex., 9 Jun 2013, 1 ex., leg. W. Guzik, a built-up area on the outskirts of a town.

4. Kotlina Sandomierska - Podgórze Rzeszowskie: Rogóżno [EA94], 1 Jun 2015, 1 ex., male, 7 Jun 2016, 1 ex., female, leg. F. Paluch, a meadow in the valley of a small creek, Markowa [EA94], 15 Jun 2015, 1 ex., male, leg. J. Bury, a wet meadow in the valley of a Markówka Creek. 
5. Kotlina Sandomierska - Podgórze Rzeszowskie: Zgłobień [EA64], 15 Jun 2015, 2 exx., male and female, 10 Jun 2016, 1 ex., female, 5 Jun 2018, 1 ex. leg. P. Czudec, a wet meadow in the valley of a small creek.

\section{Life cycle observations}

During our eight-year observation of $X$. graminea, we found that the flight period of the adults in south-eastern Poland takes about 3 weeks - from late May to mid June, with the extreme appearance dates - 30 May and 20 June. Most moths were observed in early June. At the time both male and female moths, including those fertilized, were easily attracted to different types of lamps, especially to mercury vapour and UV lamps.

The two fertilized females used for experiments in the laboratory conditions were captured on 10 and 15 June to the light of $250 \mathrm{~W}$ mercury vapour and $40 \mathrm{~W}$ UV lamps. They were placed in the plastic containers with dimensions of about 15 by 10 by $6 \mathrm{~cm}$ with about $10 \mathrm{~cm}$ long pieces of stems of two species of plants: common reed - Phragmites australis (Cav.) Trin. ex Steud. and lesser bulrush - Thypha angustifolia L. From another female captured on June 7, no eggs were obtained.
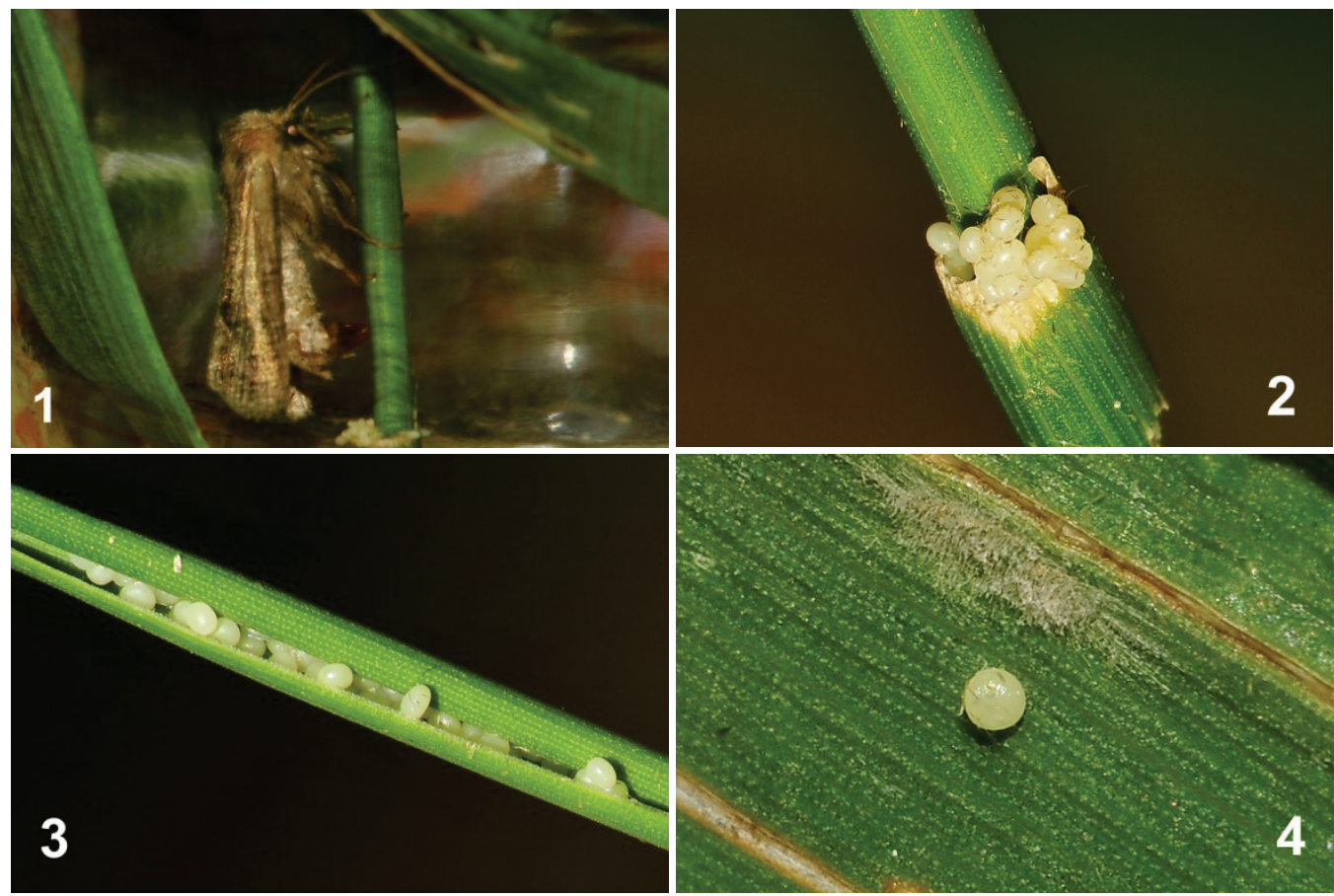

Figs 1-4. X. graminea on the common reed: 1 - Female during oviposition on the stem, 2-3 - Butch of eggs on the stem (2) and on the curled leaf (3), 4 - Single egg on the leaf surface. Photos by J. Bury.

The females laid about 110 and 70 eggs on the stems and on the leaves of Ph.australis. After finding a suitable host plant the female shows an interesting behaviour during oviposition. It goes backwards and downwards of the stem in a circular motion, at the same time looking for a convenient place to lay eggs (Fig. 1). Eggs were laid in big batches (from 35 to 20 eggs) at the base of the leaves or in the gaps of undeveloped and rolled leaves, thanks to this they were more or less hidden and almost invisible (Figs $2 \& 3$ ). In the final phase of 
oviposition eggs were oviposited in smaller clusters, in pairs or even individually. The eggs are oval and flattened, light yellow, with gentle creases on the sides (Fig. 4). The egg stage takes about 10 days.

In late June the $1^{\text {st }}$ instar caterpillars hatch and begin feeding on the host plant stems. Under laboratory conditions all caterpillars hatched on 25-26 June, 10 or 11 days after oviposition. The freshly-hatched caterpillars formed small groups (up to five-six caterpillars) and immediately started together drilling an entrance hole inside the stem of Ph. australis (Fig. 5). After entering inside of the host plant stem (Fig. 6) they occupied one internode and started feeding together. Outside the stem that has been entered, only the characteristic open entrance hole and a pile of plant particles remained after drilling the hole (Fig. 7). On a single stem more than one internode can be occupied by caterpillars at the same time. After several days of feeding the young caterpillars left the destroyed internode and moved on to a new one (Fig. 8).

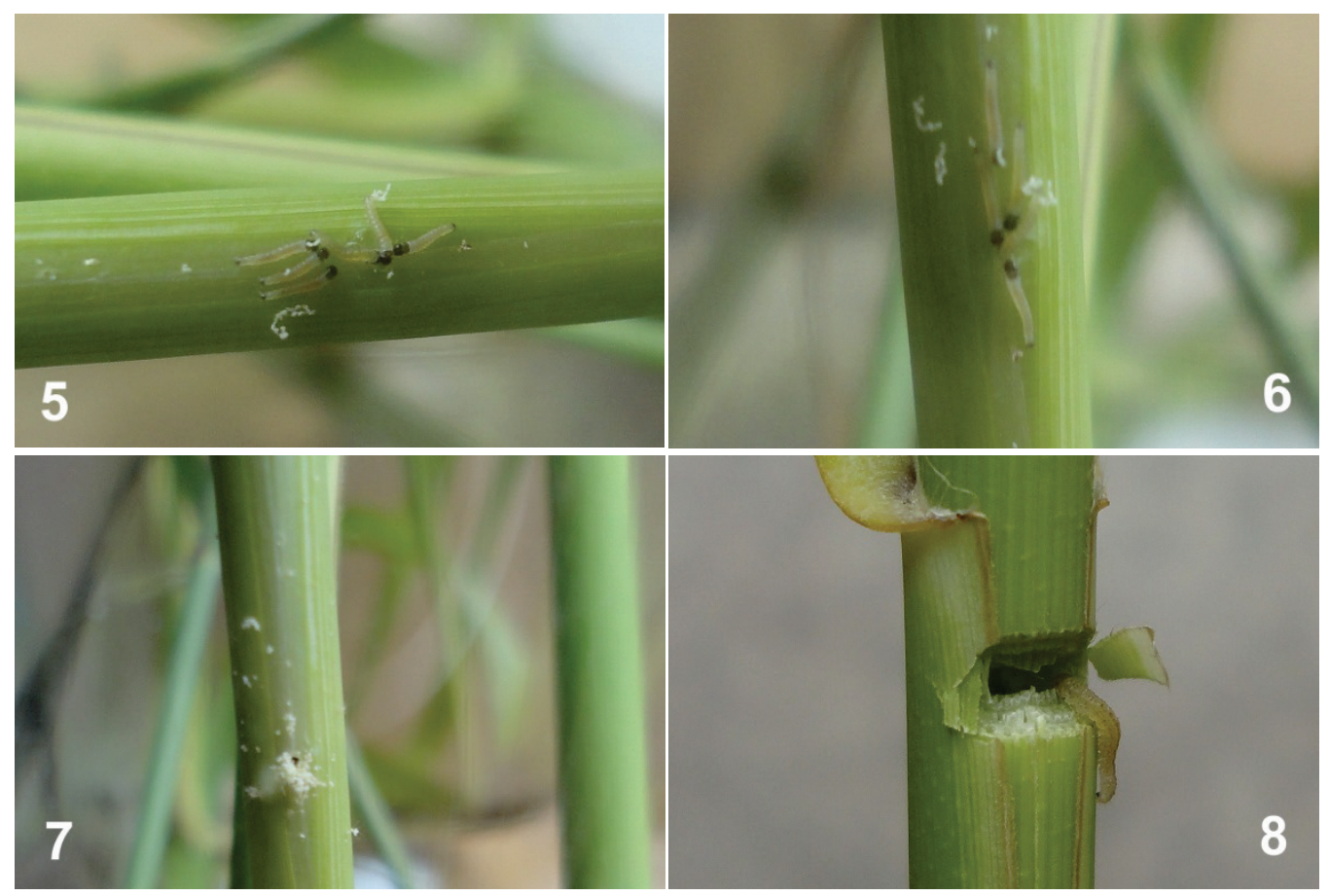

Figs 5-8. Caterpillars of $X$. graminea on the common reed: 5 - Freshly hatched caterpillars piercing a hole in the stem; 6 - Some $1^{\text {st }}$ instar caterpillars of $X$. graminea overpassing the entrance hole into the stem; 7 - The entrance hole drilled by $1^{\text {st }}$ instar caterpillars of $X$. graminea (Graeser, 1889) on the stem; $8-2^{\text {st }}$ instar caterpillar of $X$. graminea (Graeser, 1889) entering through the resected entrance window into the stem. Photos by P. Czudec.

The tests under laboratory conditions with another plans: Thypha angustifolia L. and Phalaris arundinacea L. gave negative results and showed that caterpillars of $X$. graminea are not able to feed on them.

The $2^{\text {nd }}$ and $3^{\text {rd }}$ instar caterpillars most often feed alone inside the internode (Figs 9-10). As a result of this feeding the tissue inside the internodes is completely destroyed and the empty space is filled with excrements. The undamaged external surface of the stem is diluted and in some places to becomes transparent (Fig. 11). The $3^{\text {rd }}$ instar caterpillars can change to other stems without any problem. In late August and early September the caterpillars reach a length of about $20 \mathrm{~mm}$ (Fig. 12). 


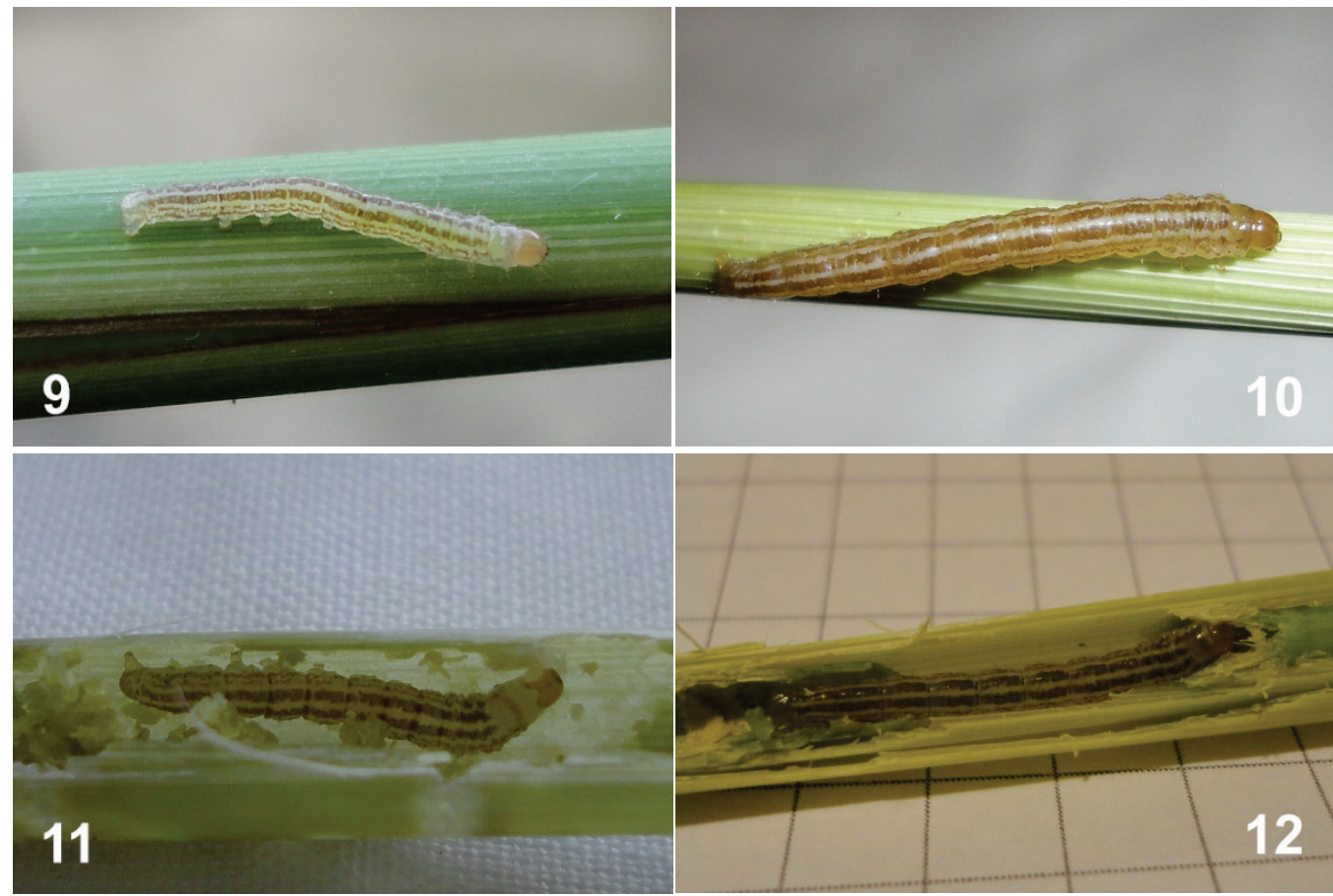

Figs 9-12. Caterpillars of $X$. graminea: $9-10-2^{\text {nd }}$ and $3^{\text {rd }}$ instar caterpillars on the surface of the common reed stem; $11-12-3^{\text {rd }}$ instar caterpillars feeding inside common reed stem. Photos by P. Czudec.

Some of the reared caterpillars in this stage were introduced to their natural environment, but were not retrieved again in the subsequent spring. The remaining caterpillars whose breeding was continued under laboratory conditions died before the overwintering, which finally ended the rearing process.

\section{DISCUSSION}

The distribution range of $X$. graminea in Poland has been expanding continuously in recent years (Fig. 13). After its first establishment in 1988 in two mesoregions Roztocze Środkowe and Roztocze Południowe within E Poland (Nowacki 1989) the species almost simultaneously was discovered in 1992 on Równina Augustowska in NE Poland (Kokot 1995). By 2000, the species had been found in a few other sites in E Poland: in Równina Łęczyńsko-Włodawska, Wysoczyzna Siedlecka, within Podlaski Przełom Bugu and in Równina Bielska (Nowacki 1993, Łupiński 1996, Nowacki \& Hołowiński 1999, Wąsala 2001, Łupiński \& Wasiluk 2002). The few additional sites discovered in Równina Augustowska and Kotlina Biebrzańska (EBS 2008, Nowacki \& Frąckiel 2010) testified only to a minor westward expansion of X. graminea in NE Poland over the last 20 years. At the same time the species was relatively frequently encountered at some of the already known localities in E and NE Poland (Nowacki \& Wasiluk 2004, EBS 2008). Since 2010, a number of new localities of the species have been discovered in SE and S Poland, which confirmed the ongoing expansion of the species in a south-west direction (Bury \& Zajda 2012, Nowacki \& Pałka 2013, 2015, Dawidowicz \& Kucharczyk 2016). 


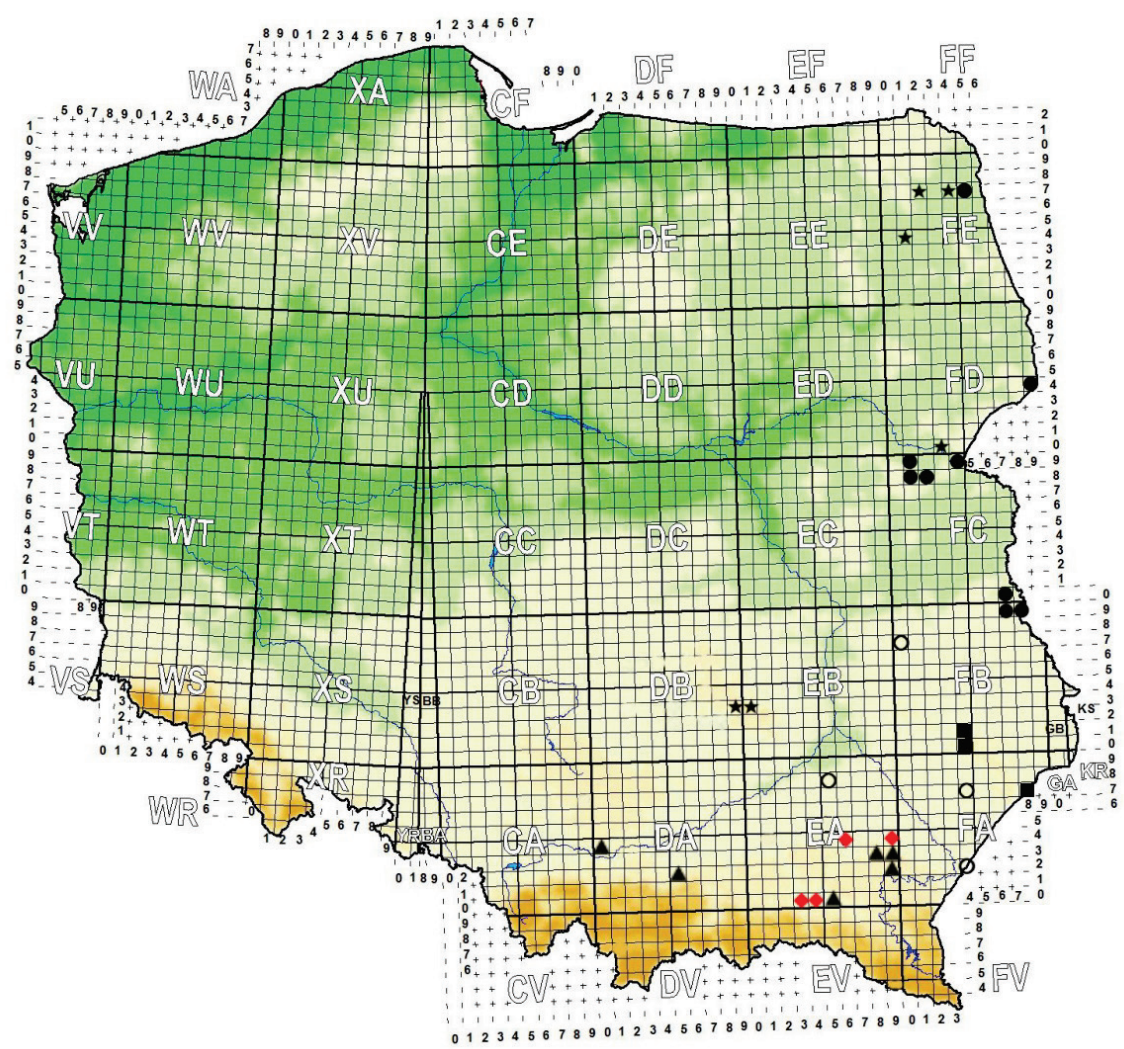

Fig. 13. Change of the distribution of Xylomoia graminea in Poland; $\mathbf{0}$ - localities discovered between 1988 and 1991 (Nowacki 1989, 1992); - localities discovered between 1992 and 2000 (Kokot 1995, Nowacki 1993, Łupiński 1996, Nowacki \& Hołowiński 1999, Wąsala 2001, Łupiński \& Wasiluk 2002, Nowacki \& Wasiluk 2004); - localities discovered between 2001 and 2009 (Nowacki \& Wasiluk 2004, EBS 2008, Nowacki \& Frąckiel 2010, Nowacki \& Nowacka 2012); $\boldsymbol{\Delta}$ - localities discovered in 2010 (Bury \& Zajda 2012); O - site discovered up to 2013 (Nowacki \& Pałka 2013, 2015, Dawidowicz \& Kucharczyk 2016); - newly discovered sites. Black symbols - data from literature, red symbols - new data.

Five recently new discovered localities of $X$. graminea are situated in four new UTM squares within two mesoregions of SE Poland, including the statements in the mesoregion of Podgórze Rzeszowskie (within Kotlina Sandomierska) where the species was not registered before. The almost third part of currently known species sites in Poland is located on Podkarpacie, half of which is situated in the center of the region (Fig. 14). This means that this part of the country is an important refugium of the species on a national scale.

For the first time it was possible to precisely determine the flight period of imagines of $X$. graminea in the climate conditions of the south-eastern Poland on the basis of eight-year observations in eleven known locations (Bury \& Zajda 2012 and this data). In addition the first successful attempt was made to rear the species in the local conditions. As a result of the ex ovo breeding process it was possible to get thorough data about the behaviour of the female during oviposition, the choice of host plant, the quantity and manner of laying eggs, the duration of the egg stage and the caterpillar feeding method up to the 3rd stage. 
Most probably the species is overwintering as a caterpillar in the $4^{\text {th }}$ stage, like it is known in the closely related species $X$. strix (Nowacki \& Pałka 2016). Unfortunately, no data on the overwintering stage as well as on the pupae were obtained. For this reason, further research into the biology of the species, especially during winter and spring period, is essential.

\section{ACKNOWLEDGEMENTS}

The authors thank all those who contributed to this article, and especially to those who have provided their material, namely Wojciech Guzik, Krzysztof Mazur and Filip Paluch.

\section{REFERENCES}

Ahola M. \& Silvonen K. 2008. Larvae of Northern European Noctuidae. Vol. 2. Viestipaino Oy., Tampere, 672 pp. BURY J. \& ZAJDA W. 2012. Distribution of Xylomoia graminea (GRAESER, 1889) (Lepidoptera: Noctuidae) in Poland review of previous studies and new data. Fragmenta Faunistica 55: 139-145. DOI: 10.3161/00159301FF2012.55.2.139

Buszko J. 2004. Sówka puszczykówka. In: AdAmski P., Bartel R., BereszysKi A., Kapel A. \& WitKowsKi Z. (eds), Gatunki Zwierząt (z wyjątkiem ptaków). Poradniki ochrony siedlisk i gatunków. Natura 2000. Podręcznik metodyczny. Ministerstwo Środowiska, Warszawa 6: 63-64.

BuszKo J. 2010. Ksylomka striks (sówka puszczykówka) Xylomoia strix MiKKOLA, 1980. In: MAKOMASKAJuCHIEWICZ M. (ed.), Monitoring gatunków zwierząt. Przewodnik metodyczny. I. Pp. 85-89. Biblioteka Monitoringu Środowiska. Inspekcja Ochrony Środowiska, Warszawa, 408 pp.

Buszko J. \& Nowacki J. 2000. The Lepidoptera of Poland, A Distributional Checklist. Polish Entomological Monographs, Poznań - Toruń, 1, 96 pp.

Dawidowicz Ł. \& KuCharczyK H. 2016. The Maria Curie-Skłodowska University Botanical Garden in Lublin as a refuge of the moths (Lepidoptera: Heterocera) within the city. Acta Biologica 23: 15-34. DOI: 10.18276/ab.2016.23-02

EUROPEAN BIODIVERSITY SURVEY (EBS) 2008. Biodiversity Survey Rospuda Valley, Final Report. Groningen, European Biodiversity Survey.

GRAESER L. 1889. Beiträge zur Kenntniss der Lepidopteren - Fauna des Amurlandes. Berliner Entomologische Zeitung 33: 309-414.

HERZ O. 1904. Lepidoptera von Korea. Noctuidae \& Geometridae. Annuaire du Museée Zoologique de l'Academie Impériale des Sciences de St. Petersbourg 9: 263-390.

Karsholt O. \& Van NiEUKerKen E. J. 2011. Fauna Europaea: Lepidoptera, Noctuidae. Fauna Europaea, version 2.4. Available at: www.faunaeur.org (31 Aug 2011)

KLYUCHKo Z. F. 1995. Xylomoia graminea (Lepidoptera, Noctuidae) - a species new for Ukrainian fauna. Journal of the Ukrainian Entomological Society 1: 38.

Klyuchko Z. F., Plyushch I. G. \& Sheshurak P. N. 2001. Annotirovannyy katalog sovok (Lepidoptera, Noctuidae) fauny Ukrainy. [The annotated catalogue of noctuids (Lepidoptera, Noctuidae) of the Ukraine fauna]. Zoology Institute of Ukrainian Academy of Sciences, Kiev: 884 pp. [In Russian]

Kокот A. 1995. Noctuid moths (Lepidoptera, Noctuidae) new to the fauna of the Puszcza Augustowska Forest. Wiadomości Entomologiczne 14: 62. [In Polish]

KONDRACKI J. 2002. Geografia regionalna Polski. Państwowe Wydawnictwo Naukowe, Warszawa, 444 pp. [Maps avalaible at: https://upload.wikimedia.org/wikipedia/commons/7/7c/Physico-Geographical_Regionalization_of_Poland.png]

LAfONTAINE J. D. \& SCHMIDT B. C. 2010. Annotated checklist of the Noctuoidea (Insecta, Lepidoptera) of North America north of Mexico. ZooKeys 40: 1-239; DOI: 10.3897/zookeys.40.414

ŁUPIŃSKI D. 1996. Co słychać w świecie motyli. [What is new in the world of butterflies] Biuletyn MTOF, 2: 26-27.

ŁUPIŃSKi D. \& WASILUK D. 2002. Motyle nocne Macroheterocera Podlaskiego Przełomu Bugu. In: DoMBROWSKI A., GŁowacki Z., Jakubowski W., Kovalchuk I., Michalczyk Z., Nikiforov M., SzWagier W. \& WojciechowsKi K. H. (eds), Korytarz ekologiczny doliny Bugu. Stan - Zagrożenia - Ochrona. Pp. 151-154. Fundacja IUCN Poland, Warszawa, 350 pp.

Mikkola K. 1980. Two new noctuid species from Northern Europe: Polia sabmeana n. sp. and Xylomoia strix n. sp. (Lepidoptera, Noctuidae: Hadeninae and Amphipyrinae). Notulae Entomologicae 60: 217-222.

MiKKOLA K. 1998. Revision of the genus Xylomoia Staudinger (Lepidoptera: Noctuidae), with descriptions of two new species. Systematic Entomology 23: 173-186.

NOWACKI J. 1989. Xylomoia graminea (GRAESER, 1888) nowy dla fauny Polski i Europy przedstawiciel sówkowatych (Lepidoptera, Noctuidae). Przegląd Zoologiczny 33: 445-447.

NowACKI J. 1992. Sówkowate (Lepidoptera, Noctuidae) Roztocza. Fragmenta Faunistica 35: 397-414. DOI: 10.3161/00159301FF1992.35.24.397

NOWACKI J. 1993. Nowe stanowiska sówkowatych (Lepidoptera, Noctuidae) w Polsce. Wiadomości entomologiczne 12: 62.

NOWACKI J. 1998. The Noctuids (Lepidoptera, Noctuidae) of central Europe. Bratislava, 143 pp. 
NOWACKI J. \& FRACKIEL K. 2010. The influence of anthropogenic factors on the biodiversity of noctuid moths (Lepidoptera, Noctuidae) in marsh habitats of the Biebrza valley. Polish Journal of Entomology 79: 307-318.

NowACKI J. \& HoŁOWIŃSKi M. 1999. Sówkowate (Lepidoptera, Noctuidae) Lasów Sobiborskich. Wiadomości entomologiczne 18 (Supl. 1): 1-60.

NOWACKI J. \& NowACKA J. 2012. Materiały do poznania sówkowatych (Lepidoptera: Noctuidae) Gór Świętokrzyskich. Wiadomości entomologiczne 31: 35-40.

NOWACKI J. \& PAŁKA K. 2013. Contribution to the knowledge of distribution of the noctuid moths (Lepidoptera: Noctuidae) of eastern Poland. Wiadomości entomologiczne 32: 139-146.

NowACKi J. \& PAŁKA K. 2014. New record of Xylomoia strix MikKolA, 1980 (Lepidoptera: Noctuidae) in Poland. Wiadomości entomologiczne 33: 38-41.

NowACKI J. \& PAŁKA K. 2015. Noctuid moths (Lepidoptera: Noctuoidea: Nolidae, Erebidae, Noctuidae) of the Nowa Dęba Military Training Area in the Sandomierz Primeval Forest (south-eastern Poland). Fragmenta Faunistica 58: 21-36. DOI: 10.3161/00159301FF2015.58.1.021

NowACKi J. \& PAŁKA K. 2016. Xylomoia strix Mikkola, 1980 in Poland with comments on its biology and ecology (Lepidoptera: Noctuidae). SHILAP Revista de Lepidopterología 44: 271-279.

NOWACKI J. \& WASILUK D. 2004. Sówkowate (Lepidoptera, Noctuidae) południowego Podlasia. Wiadomości entomologiczne 23 (Suplement): 1-48.

POLTAVSKY A.N. \& ARTOHIN K.S. 2000. New and rare Macrolepidoptera of the Rostov-on-Don region in South Russia (Lepidoptera). Phegea 28: 131-147.

Sugi S. 1982. Noctuidae. In: Inaue H., Sugi S., Kuroko H., Moriuti S. \& Kawabe A. (eds), Moths of Japan. I. Text. Kadansha, Tokyo, 669-913.

SVIRIDOV A.V. 1985. Material for knowledge of the fauna of Noctuidae (Lepidoptera) of the northern Amur Area. Sbornik Trudy Zoologicheskogo Muzeya MGU 23: 155-182.

ŠviTRA G., BAČIANSKAS V., ŪSAITIS T. \& LUKOŠEVIČIUS D. 2011. Four new and 153 rare for the Lithuanian fauna Lepidoptera species recorded in 2011. New and rare for Lithuania insect species 23: 67-93.

OlBRYCHT T. \& BuRY J. 2011. Specjalny obszar ochrony siedlisk Nad Husowem (PLH180025). In: RogAŁA D. \& Marcela A. (eds), Obszary NATURA 2000 na Podkarpaciu. Pp. 236-239. Regionalna Dyrekcja Ochrony Środowiska, Rzeszów.

Wąsala R. 2001. Xylomoia graminea (GrAeser) (Lepidoptera: Noctuidae) gatunek nowy dla fauny Puszczy Białowieskiej. Wiadomości entomologiczne 20: 280.

ZiLli A., RonKAY L. \& Fibiger M. 2005. Noctuidae Europaeae. Vol. 8, Apameini. Entomological Press, Sorø, 323 pp.

\section{STRESZCZENIE}

\section{[Uwagi na temat rozmieszczenia oraz biologii Xylomoia graminea (Graeser, 1889) (Lepidoptera: Noctuidae) w południowo-wschodniej Polsce]}

Praca przedstawia wyniki badań nad rozmieszczeniem i biologią $X$. graminea wykonanych na terenie Polski południowo-wschodniej w latach 2012-2018. W okresie badań odkryto pięć nowych stanowisk gatunku zlokalizowanych w czterech nowych kwadratach UTM (10 x 10 km) w obrębie dwóch mezoregionów, przy czym w Regionie Podgórza Rzeszowskiego należącego do makroregionu Kotliny Sandomierskiej, gatunek ten nie był wcześniej rejestrowany. Aktualnie, niemal jedna trzecia znanych stanowisk $X$. graminea w Polsce jest zlokalizowana $\mathrm{w}$ obrębie Podkarpacia, co czyni ten region ważnym refugium gatunku $\mathrm{w}$ skali całego kraju. Ponadto, na podstawie danych zebranych w latach 2012-2018 ustalono fenologię pojawu imagines $X$. graminea w warunkach południowo-wschodniej Polski.

Należy zaznaczyć, że po raz pierwszy na terenie naszego kraju podjęto udaną próbę hodowli gatunku ex ovo, co pozwoliło ustalić nieznane dotychczas szczegóły jego biologii - zachowanie samicy w trakcie składania jaj, wybór rośliny żywicielskiej, sposób oraz ilość składanych jaj, czas trwania stadium jaja oraz wygląd i sposób żerowania gąsienic do osiągnięcia III-go stadium rozwojowego, tuż przed zimowaniem. Wszystko to udokumentowano zdjęciami.

Niestety nie udało się jednoznacznie ustalić stadium, w którym $X$. graminea zimuje, jak też nie uzyskano poczwarki. $Z$ tego względu konieczne są dalsze badania nad biologią gatunku, zwłaszcza dotyczące fazy hibernacji oraz okresu po przezimowaniu. 